\title{
ANTHELMINTHIC EFFECT OF TAMOXIFEN ON EXPERIMENTALLY HYMENOLEPIS NANA INFECTED MICE
}

\author{
By
}

AMANY F.EL FAKAHANY, MOHAMED H. S. IBRAHIM, ATEF H. HUSSEIN, NAGLAA A. M. EL SAWY AND HEMAT S. M. ALI*

Department of Parasitology, Faculty of Medicine, Benha University, Benha, Egypt

( ${ }^{*}$ Correspondence:hemat_salah@yahoo.com)

\section{Abstract}

Hymenolepis nana is one of the commonest parasites worldwide especially in children. Praziquantel was the most effective drug in hymenolepiasis treatment, but with the risk of resistance development. There was a need for search for $\operatorname{drug}(\mathrm{s})$ to overcome this problem. Tamoxifen (an estrogen-receptor modulator), is available, low cost with potential anti-parasitic efficacy. This study assessed the therapeutic effect of tamoxifen drug on mice experimentally infected mice with $H$. nana at different developmental stages. Clean laboratory bred mice infected with $H$. nana eggs were divided into 4 groups according to different schedule of tamoxifen administration $(20 \mathrm{mg} / \mathrm{kg}$ body weight) at the parasite different developmental stages and control one (infected non treated). At the experimental mice were sacrificed and parasitological evaluated for worm burden count, their weight, egg count and viability. The results did not show statistically significant effect on worm burden as compared to control one, with the exception of mice treated two days post-infection that showed significant increase in worm burden. There was significant decrease in worm weight, egg count and viability as compared to control ones, but without difference between different treated groups.

Keywords: Mice, Hymenolepis nana, Tamoxifen ${ }^{\circledR}$, Parasitological evaluation.

\section{Introduction}

Hymenolepis nana or the dwarf tapeworm is a worldwide prevalent zoonotic parasitic disease. It is one of the commonest cestode infections among rodents and man (Sadaf et $a l, 2013)$. It is widespread parasite of children owing to the lack of fecal sanitation together with bad feeding practice (Mirdha and Samantray, 2002). The three drugs used for the hymenolepiasis treatment were praziquantel, nitazoxanide, and niclosamide, with praziquantel (PZQ) the drug of choice for $H$ nana (Juan et al, 2002). Indication of the development of PZQ resistance by other parasites appeared over recent decades (Beshay, 2017). Additionally, PZQ tablets are large, taste bitter, without readily available pediatric formulation (Cioli et al, 2014). Tamoxifen is the most used selective estrogen-receptor modulator to prevent and treat estrogen receptor positive breast cancer (Bogush et al, 2018), as well as antibacterial, antiviral and anti-parasitosis against echinococcosis and leishmaniasis (Bogush et al, 2012). Tamoxifen is cheap, safety and worldwide available (WHO, 2019).
The present study aimed to evaluate Tamoxifen ${ }^{\mathbb{B}}$ activity on mice experimentally infected with Hymenolepis nana and its different life cycle stages.

\section{Materials and methods}

The study was conducted at the experimental animal house of Department of Parasitology, Benha Faculty of Medicine, from October 2018 to January 2019.

Parasite: Hymenolepis nana eggs were obtained fresh from stool samples of infected patient and inoculated into rats to have a laboratory strain.

Fresh stool samples were collected in dry clean containers from patients attended Pediatric Department, Benha University's Hospitals. Stool samples were examined microscopically to insure $H$. nana eggs (Garcia and Bruckner, 1997) and the egg viability was confirmed by using Chausov's methodlogy (Moazeni and Rakhshandehroo, 2011). The dead eggs acquired a yellow color within 20 minutes, the oncospheres turned orange and magenta, but living eggs was yellow in color and spherical or subspherical oncosphere in closed in a thick membrane; embry- 
ophore, and armed with six hooks: same as hexacanth embryo (Ridley, 2011). The collected eggs were then administered orally by using a tuberculin syringe to experiment with mice groups. Examination of stool of infected mice to confirm infection was done 2 weeks post-infection by direct smear method (Ferretti et al, 1980). Dilution in normal saline and sieving for each sample was done. The collected fluid was then left to concentrate by sedimentation at room temperature for 1 to $3 \mathrm{hrs}$ or very carefully centrifuged ( 5 to 7 minutes at a rate of 500 revolutions/ minute). Mice were sacrificed three weeks post-infection, by ether inhalation in a closed container. Each mouse was dissected and small intestine was removed and put in a Petri-dish with normal physiological saline and left for half an hour to release the worms from the intestinal mucous. Intestine was then slit opened, the worms were released and the gravid segments of adult worms were recovered and homogenized to get the eggs.

Experimental animals: One hundred labora tory-bred male Swiss albino mice, 6-8 weeks old, weighed about $20-25 \mathrm{gm}$ each were used in both $H$. nana maintenance and in experimental study in clean metallic cages. They were allowed bread mixed with barely, crushed corn and beans in a ratio 3:2:1 \& water was provided in hanging bottles. Cages were kept in the animal house under daily observations

Tamoxifen $^{\circledR}$ was obtained from Egyptian International Pharmaceutical Industries Co. (EPICO) each tablet contained 40mg. The tablets were dissolved in sunflower oil (Sigma-Aldrich) and given orally by tuberculin syringe at a dose of $20 \mathrm{mg} / \mathrm{kg}$ body weight (Nicolao et al, 2014).

Infection design: Parasite-free mice received orally a dose of about 200 Hymenolepis nana eggs/mouse, using a syringe with curved esophageal needle specifically to infect mice. Infected mice were divided into 5 groups: G1: 20-infected mice orally treated with tamoxifen $\left(20 \mathrm{mg} / \mathrm{kg}\right.$ orally) at $2^{\text {nd }}$ day post- infection for 3 successive days to evaluate the drug effect upon the cysticercoids. G2: 20 -infected mice treated orally with tamoxifen $(20 \mathrm{mg} / \mathrm{kg})$ at $6^{\text {th }}$ day post-infection for 3 successive days to evaluate the drug action upon juvenile form. G3: 20-infected mice treated orally with tamoxifen $(20 \mathrm{mg} / \mathrm{kg})$ at $10^{\text {th }}$ day post-infection for 3 successive days to evaluate the drug action on immature worms, not yet initiated oviposition. G4: 20-infected mice treated orally with tamoxifen $(20 \mathrm{mg} / \mathrm{kg})$ at $14^{\text {th }}$ day post-infection for 3 successive days to evaluate the drug action on mature worm laying eggs. G5: 20-infected, non-treated (infected control) to evaluate the parasite normal development in comparison with the drug treated mice.

Drug efficacy on total worm burden: Mice were sacrificed 20 days post-infection and the small intestines were removed, each one in a Petri-dish containing normal saline and left for sometimes then small intestines were dissected and the petri-dishes were examined to recover the free worm mucosa. Worm' affected was identified based on the morphology of scolex, mature segments, ova in gravid segments and each worm weight in $\mathrm{mg}$.

Egg counting: Worms were separately crushed and the average eggs number was microscopically counted.

Egg viability: A vital staining method was used to confirm viability (Chausov, 1964).

Statistical analysis; Data were collected, tabulated and analyzed using the statistical package SPSS version 12. Data were given as mean and standard deviation (SD) for quantitative variables and percent for qualitative variables. Fisher exact test was used to compare between groups and $\mathrm{P}$ values $<0.05$ were considered significant.

\section{Results}

The present study did not show significant reduction in worm burden in infected mice treated with tamoxifen as compared to control ones $(\mathrm{P}>0.05)$ with exception of mice started treatment two days post-infection. This group showed an increase in worm burden as compared to control one (Tab.1). Also, 
comparing the results of groups treated with different schedules showed no significant difference $(\mathrm{P}>0.05)$ in worm burden except mice treated after two days post-infection, where the worm burden was significantly higher than in other groups $(\mathrm{P}<0.05)$. There was a highly significant reduction in worm weight $(\mathrm{P}<0.001)$ in infected mice treated with tamoxifen when compared with control ones (Tab. 2). By comparing the results of mice treated with different schedules did not show significant difference $(\mathrm{P}>0.05)$ in worm's weight. There was a highly significant reduction in $H$. nana egg count $(\mathrm{P}<0.001)$ in infected mice treated with tamoxifen when compared with the control ones (Tab. 3 ). By comparing results in mice treated with different schedules did not show significant difference $(\mathrm{P}>0.05)$ in egg count, buta highly significant reduction in percentage of viable eggs $(\mathrm{P}<0.001)$ in infected mice treated with tamoxifen when compared with the control ones (Tab. 4). Also, comparing the results in mice treated with the different drug schedules did not show significant difference $(\mathrm{P}>0.05)$ in viable eggs percentage.

Table 1: Tamoxifen efficacy on $H$.nana worm burden in mice intestine

\begin{tabular}{|c|c|c|c|c|c|c|c|c|}
\hline \multirow{3}{*}{$\begin{array}{l}\text { Mice } \\
\text { group }\end{array}$} & \multirow{3}{*}{$\begin{array}{c}\text { Mice } \\
\text { number }\end{array}$} & \multirow{2}{*}{\multicolumn{2}{|c|}{$\begin{array}{c}\text { Worm burden } \\
\text { per mice }\end{array}$}} & \multicolumn{5}{|c|}{ Pairwise group significance } \\
\hline & & & & \multicolumn{5}{|c|}{$\mathrm{P}$ value against other groups in order } \\
\hline & & Mean & $\mathrm{SD}$ & G 1 & G2 & G3 & G4 & G5 \\
\hline G1 & 20 & 2.83 & 2.29 & - & $<0.05 *$ & $<0.05 *$ & $<0.05 *$ & $<0.05 *$ \\
\hline $\mathrm{G} 2$ & 20 & 1.75 & 1.0 & $<0.05 *$ & - & $>0.05$ & $>0.05$ & $>0.05$ \\
\hline G3 & 20 & 1.76 & 1.0 & $<0.05 *$ & $>0.05$ & - & $>0.05$ & $>0.05$ \\
\hline G4 & 20 & 1.74 & 1.0 & $<0.05 *$ & $>0.05$ & $>0.05$ & - & $>0.05$ \\
\hline G5 & 20 & 1.85 & 1.0 & $<0.05 *$ & $>0.05$ & $>0.05$ & $>0.05$ & - \\
\hline
\end{tabular}

Table 2: Tamoxifen efficacy on weight of $H$. nana worm

\begin{tabular}{|l|l|c|c|c|c|c|c|c|}
\hline Mice & \multirow{2}{*}{$\begin{array}{l}\text { Mice } \\
\text { group }\end{array}$} & \multicolumn{2}{|c|}{$\begin{array}{l}\text { Worm weight } \\
\text { number }\end{array}$} & \multicolumn{2}{|c|}{$(\mathrm{mg})$} & \multicolumn{2}{|c|}{ Pairwise group significance } \\
\cline { 3 - 9 } & & Mean & SD & G 1 & G2 & G3 & G4 & G5 \\
\hline G1 & 20 & 6.8 & 2.73 & - & $>0.05$ & $>0.05$ & $>0.05$ & $<0.001^{* *}$ \\
\hline G2 & 20 & 6.9 & 2.53 & $>0.05$ & - & $>0.05$ & $>0.05$ & $<0.001^{* *}$ \\
\hline G3 & 20 & 6.73 & 2.53 & $>0.05$ & $>0.05$ & - & $>0.05$ & $<0.001^{* *}$ \\
\hline G4 & 20 & 7.47 & 2.94 & $>0.05$ & $>0.05$ & $>0.05$ & - & $<0.001^{* *}$ \\
\hline G5 & 20 & 11.0 & 3.08 & $<0.001^{* *}$ & $<0.001^{* *}$ & $<0.001^{* *}$ & $<0.001^{* *}$ & - \\
\hline
\end{tabular}

Table 3: Tamoxifen efficacy on $H$.nana egg count

\begin{tabular}{|l|c|c|c|c|c|c|c|c|}
\hline \multirow{2}{*}{$\begin{array}{l}\text { Mice } \\
\text { group }\end{array}$} & \multirow{2}{*}{$\begin{array}{c}\text { Mice } \\
\text { number }\end{array}$} & \multicolumn{2}{|c|}{$\begin{array}{c}\text { Egg count } \\
\text { per worm }\end{array}$} & \multicolumn{5}{|c|}{ Pairwise group significance } \\
\cline { 3 - 9 } & & Mean & SD & G 1 & G2 & G3 & G4 & G5 \\
\hline G1 & 20 & 8245.71 & 2414.7 & - & $>0.05$ & $>0.05$ & $>0.05$ & $<0.001^{* *}$ \\
\hline G2 & 20 & 7760.97 & 2105.34 & $>0.05$ & - & $>0.05$ & $>0.05$ & $<0.001^{* *}$ \\
\hline G3 & 20 & 8506.12 & 2219.27 & $>0.05$ & $>0.05$ & - & $>0.05$ & $<0.001^{* *}$ \\
\hline G4 & 20 & 8686.84 & 2286.05 & $>0.05$ & $>0.05$ & $>0.05$ & - & $<0.001^{* *}$ \\
\hline G5 & 20 & 12129.82 & 2358.42 & $<0.001^{* *}$ & $<0.001^{* *}$ & $<0.001^{* *}$ & $<0.001^{* *}$ & - \\
\hline
\end{tabular}

$* *$ highly significant difference

Table 4: Tamoxifen efficacy on $H$.nana eggs viability

\begin{tabular}{|l|c|c|c|c|c|c|c|c|}
\hline \multirow{2}{*}{$\begin{array}{l}\text { Mice } \\
\text { group }\end{array}$} & \multirow{2}{*}{$\begin{array}{c}\text { Mice } \\
\text { number }\end{array}$} & \multicolumn{2}{|c|}{$\begin{array}{c}\text { Viable egg } \\
\text { percentage }\end{array}$} & \multicolumn{5}{|c|}{ Pairwise group significance } \\
\cline { 3 - 9 } & & Mean & SD & G 1 & G2 & G3 & G4 & G5 \\
\hline G1 & 20 & 36.47 & 8.76 & - & $>0.05$ & $>0.05$ & $>0.05$ & $<0.001^{* *}$ \\
\hline G2 & 20 & 36.85 & 13.52 & $>0.05$ & - & $>0.05$ & $>0.05$ & $<0.001^{* *}$ \\
\hline G3 & 20 & 34.72 & 7.16 & $>0.05$ & $>0.05$ & - & $>0.05$ & $<0.001^{* *}$ \\
\hline G4 & 20 & 33.64 & 10.74 & $>0.05$ & $>0.05$ & $>0.05$ & - & $<0.001^{* *}$ \\
\hline G5 & 20 & 71.47 & 12.93 & $<0.001^{* *}$ & $<0.001^{* *}$ & $<0.001^{* *}$ & $<0.001^{* *}$ & - \\
\hline
\end{tabular}

\section{Discussion}

Hymenolepis nana is the commonest worm infected man worldwide (Smyth, 1994). In fection can persist for years by auto infection (Cho et al, 2009). Praziquantel is effective against $H$. nana. But, frequent drug reg- 
imens were necessary to organize spreading infections especially in institutional and familial settings. Besides, the incomplete understanding of its mechanism of action delayed efforts to combat its resistance (Murray and Baron 2007; Doenhoff et al, 2008).

In the present study, tamoxifen on the worm burden showed no significant effect. Besides, there was unexplained significant increase in mice treated at two days post infection. The present results showed that tamoxifen did not affect the adult worm. This disagreed with Escobedo et al. (2013) who found that tamoxifen caused a strong cysticidal and antitaeniasic effect on Taenia soli$u m$. The present results also disagreed with Miguel et al. (2009) and Eissa et al. (2011) who reported that tamoxifen had good efficacy on L. braziliensis and L. chagasi infected animals, with marked reduction of parasite burden at lesion site or liver and spleen by about $99 \%$ \& $95 \%$ to $98 \%$ respectively. The present study showed a highly significant reduction in $H$. nana weight in infected mice treated with tamoxifen as compared to control ones. This find agreed with Nicolao et al. (2014) who evaluated the tamoxifen effect against larval stages of Echinococcus granulosus in-vitro and in-vivo that showed reduction in cyst weight. In the present study, tamoxifen affected egg count and viability with significant reduction in both. This result coincided with the theory that tamoxifen is estrogen receptor modulator affecting parasitic fecundity more than the adult itself. More studies are needed to study drug effect and mechanism of action.

\section{Conclusion}

To the best of knowledge, none has evaluated tamoxifen ${ }^{\circledR}$ efficacy on Hymenolepis nana. Data showed that tamoxifen affected $H$. nana by reduction its egg count and viability, but without effect on the worm burden.

\section{References}

Beshay, EVN, 2017: Therapeutic efficacy of Artemisia absinthium against Hymenolepis na$n a$ : In vitro and in vivo studies in comparison spherical or subspherical stage, enclosed in a thick membrane, the embryophore, and armed with six hooks: same as hexacanth embryo. with the anthelmintic Praziquantel. J. Helminthol. 13: $1-11$.

Moazeni, M, Rakhshandehroo, E, 2011: In vitro viability test for the eggs of Echinococcus granulosus: A rapid method. Parasitol. Res. 110, 2:925-30

Bogush, TA, Polezhaev, BB, Mamichev, IA, Bogush, EA, Polotsky, BE, et al, 2018: Tamoxifen never ceases to amaze: New findings on nonestrogen receptor molecular targets and mediated effects. Cancer Invest. 36:211-20.

Chai, JY, 2013: Praziquantel treatment in trematode and cestode infections: An update. Infect. Chemother. 45, 1:32-43.

Cho, SC, Lee, HL, Lee, OY, Yoon, BC, Choi, HS, et al, 2009: Hymenolepis nana infection of the colon in an adult male. Gastrointest. Endosc.70, 4:784-5.

Cioli, D, Pica-Mattoccia, L, Basso A, Guidi, A, 2014: Schistosomiasis control: Praziquantel forever?. Mol. Biochem. Parasitol. 195, 1:23-9.

Doenhoff, MJ, Cioli, D, Utzinger, J, 2008: Praziquantel: Mechanisms of action, resistance and new derivatives for schistosomiasis. Curr. Opin. Infect. Dis. 21, 6:659-67.

Eissa, MM, Amer, I, El-Sawy, SMF, 2011: $L e$ ishmania major: Activity of tamoxifen against experimental cutaneous leishmaniasis. Exp. Parasitol. 128, 4:382-90.

Escobedo, G, Palacios-Arreola, MI, Olivos, A, López-Griego, L, Morales-Montor, J, 2013: Tamoxifen treatment in hamsters induces protection during taeniosis by Taenia solium. Biomed Res. Inter. 2013; 2013:280496.

Ferretti, G, Gabriele, F, Palmas, C, 1980: Methodology in experimental infections of mice with Hymenolepis nana. Boll. Zool. 47:165-84.

Garcia, LS, Bruckner, DA, 1997: Fixation and special preparation of fecal parasite specimens and arthropods. In: Diagnosis Parasitology Washington: ASM Press.

Juan, JO, Lopez Chegne, N, Gargala, G, Favennec, L, 2002: Comparative clinical studies of nitazoxanide, albendazole and praziquantel in the treatment of ascariasis, trichuriasis and hymenolepiasis in children from Peru. Trans. R. Soc. Trop. Med. Hyg. 96, 2: 193-6.

Miguel, DC, Zauli-Nascimento, RC, Yokoyama, JK, Katz, S, Barbiéri, CL, Uliana, SRB, 2009: Tamoxifen as a potential anti-leishmanial agent: Efficacy in treatment of Leishmania braziliensis and Leishmania chagasi infections. J. 
Antimicrobial. Chemother. 63, 2:365-8.

Mirdha, BR, Samantray, JC, 2002: Hymenolepis nana: A common cause of pediatric diarrhea in urban, slum dwellers in India. J. Trop. Paediatr. 48:331-6.

Murray, PR, Baron, EJ, 2007: Manual of Clinical Microbiology. Washington, DC, ASM Press.

Nicolao MC, Elissondo MC, Denegri GM, Goya, AB, Cumino AC, 2014: In vitro and in vivo effects of tamoxifen against larval stage $E c$ hinococcus granulosus. Antimicrobial. Agents Chemother. 58, 9:5146-54.

Ridley, J, 2011: Parasitology for Medical and
Clinical Laboratory Professionals. ISBN: 1-13341701-9.

Sadaf, H, Khan, S, Kanwal, N, Tasawer, B, Ajmal, S, 2013: A review on diarrhea causing Hymenolepis nana-dwarf tapeworm. Inter. Res. J. Pharm. 4:e32-5.

Smyth, JD, 1994: Eucestoda: Cyclophyllidea. In: Introduction to Animal Parasitology. Cambridge; Cambridge University Press.

WHO, 2019: Model List of Essential Medicines, the $21^{\text {st }}$ List. https://apps.who.int/iris/bitstream/ handle/10665/325771/WHOMVP-EMPIAU.06 eng. pdf?ua $=1$

\section{Explanation of figure}

Fig.1-A: H. nana egg obtained from crushed worms, B: H. nana egg in unstained stool smear (x10).C: Chausov methodology showed viable H.nana egg with yellow onchosphere against pinkish background (x10).D: Dead H. nana egg : by using chausov methodology showed onchosphere with magenta color (x10)

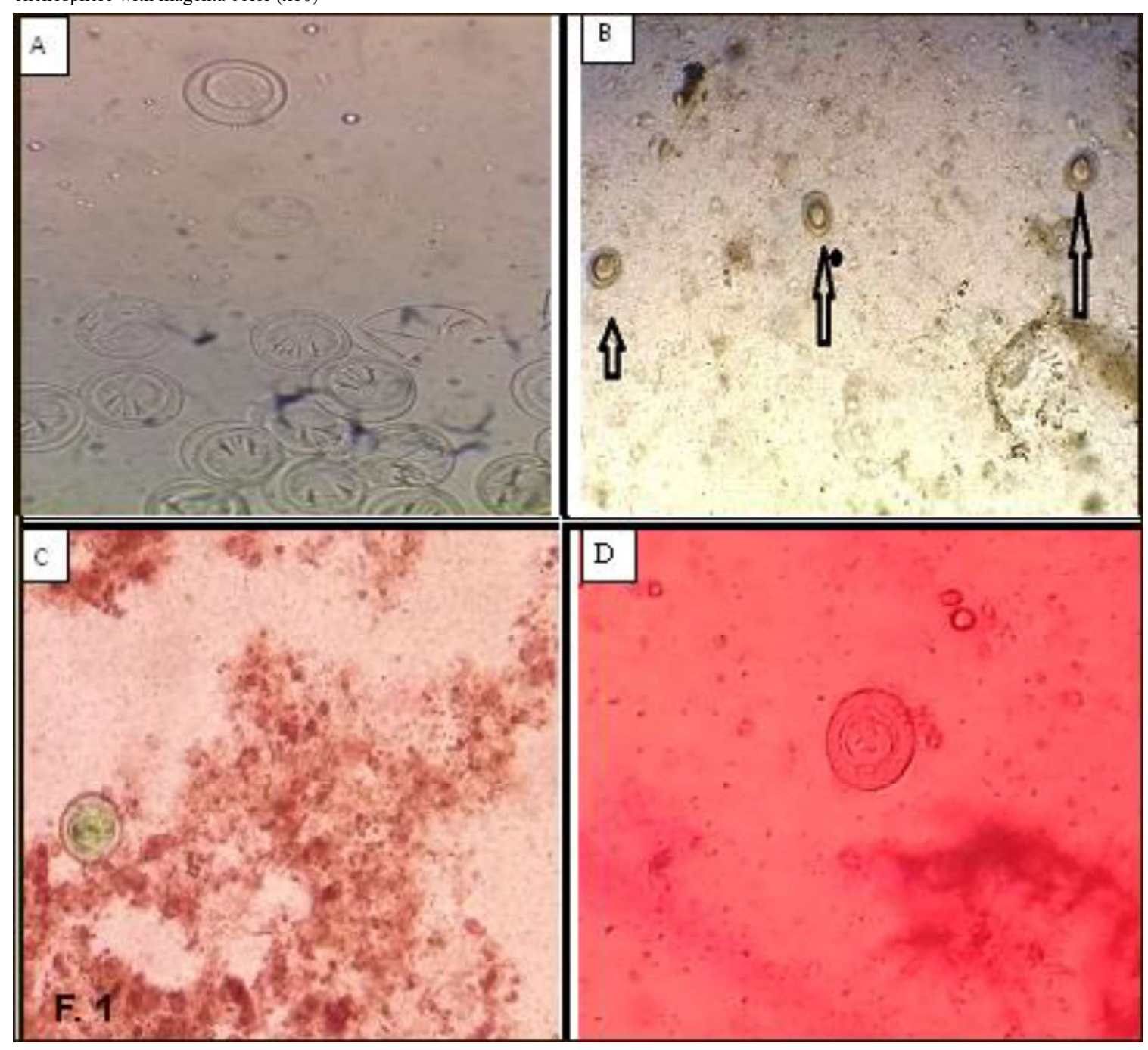

